Reprinted from J, Mol. Biol. (1972) 65, 375-378

More Evidence for a Particle Character of Aminoacyl-transfer RNA Synthetases isolated from Rat Liver

Cluavia J. G. M. Vennegoor, A. L. H. Stols and H. Blohmerddat 



\title{
More Evidence for a Particle Character of Aminoacyl-transfer RNA Synthetases isolated from Rat Liver
}

\begin{abstract}
Glutaminyl-, isoleucyl-, leucyl-, lysyl- and methionyl-transfer RNA synthetase can be isolated from a postmicrosomal fraction from rat liver as a complex which resists separation in the following techniques: gel filtration on Sephadex G200, chromatography on DEAE-Sephadex A50, chromatography on DEAE-Sephadex A50, chromatography on hydroxyapatite, centrifugation in sucrose gradients and isoelectric focusing. The complex has a sedimentation coefficient of $18 \mathrm{~s}$. In the electron microscope it appears as an organized structure of well-defined size and shape. These observations might provide additional evidence for the particle character of aminoacyl-transfer RNA synthetases.
\end{abstract}

A post-microsomal fraction, which has been isolated from rat liver by centrifugation for 15 hours at $100,000 \mathrm{~g}$, stimulates the incorporation of amino acids in a cell-free system (Hoagland \& Askonas, 1963; Mizrahi, 1965; Parthier \& Hultin, 1967; Vennegoor \& Bloemendal, 1970). The effect of this fraction, designated X-fraction by Hoagland, was attributed to different functions, namely messenger RNA (Hoagland \& Askonas, 1963), interaction between free ribosomes and messenger RNA (Mizrahi, 1965) and aminoacyl-transfer RNA transferase (Parthier \& Hultin, 1967). However, our investigation on the action of the $\mathrm{X}$-fraction suggested that its activity should be ascribed to aminoacyl-transfer RNA synthetases (Vennegoor \& Bloemendal, 1970).

In a recent paper in this journal, it has been reported that a high molecular weight complex, containing all aminoacyl-tRNA synthetases, can be isolated from rat liver (Bandyopadhyay \& Deutscher, 1971). Upon determination of the activity of 20 aminoacyl-tRNA synthetases in the $\mathrm{X}$-fraction and in its supernatant fraction, we observed that glutaminyl-, isoleucyl-, leucyl-, lysyl- and methionyl-tRNA synthetases were concentrated to a greater extent in the X-fraction than the other enzymes (Table 1). During further purification on Sephadex G200, DEAE-Sephadex A50, hydroxyapatite, and characterization by centrifugation in sucrose gradients and by isoelectric focusing the major activities of the five synthetases always coincided. The purification achieved after each fractionation step, expressed in relative units per mg protein, is depicted in Table 2 (values given in parentheses). Table 2 also shows that the relative distribution of the five enzymes in the complex remained reasonably constant during purification except after isoelectric focusing. As the latter procedure took 72 hours, the observed shift in the ratios may be caused by a gradual loss of enzymic activity being different for the individual enzymes. The main activity, of the five enzymes, however, always accumulated at the same isoelectric point, namely $\mathrm{p} I 5 \cdot 7$. Some activity concentrated at $\mathrm{p} I 6 \cdot 1$ and $6 \cdot 5$ (see Table 3). After gel filtration on Sephadex G200, the protein peak still contained a considerable amount of tRNA ( $10 \%$ of the total weight of protein). This tRNA was removed by subsequent chromatography on DEAE-Sephadex A50. Despite the removal of RNA, the aminoacyl-tRNA synthetases remained in an aggregated state. This could be deduced from the results obtained after centrifugation of the purified fraction in an isokinetic sucrose gradient prepared according to Noll (1969) (see Fig. 1). Using the lens proteins 
TABLI 1

Distribution of aminoacyl-tRNA synthetases in supernatant $X$ and in the $X$-fraction

\begin{tabular}{|c|c|c|}
\hline Amino acid & $\begin{array}{r}\text { Supernatant } \mathbf{X} \\
\text { Percentage }\end{array}$ & $\begin{array}{l}\text { X-fraction } \\
\text { of activity }\end{array}$ \\
\hline Alenine & 82 & 18 \\
\hline Arginine & 63 & 47 \\
\hline Asparagine & 66 & 34 \\
\hline Aspartic aoid & 77 & 23 \\
\hline Cysteine & 79 & 21 \\
\hline Glutamic acid & 38 & 62 \\
\hline Glutamine & 13 & 87 \\
\hline Glycine & 75 & 25 \\
\hline Histidine & 78 & 22 \\
\hline Isoleucine & 20 & 80 \\
\hline Leucine & 20 & 80 \\
\hline Lysine & 8 & 92 \\
\hline Methionine & 14 & 86 \\
\hline Phenylalenine & 62 & 38 \\
\hline Proline & 63 & $\mathbf{3 7}$ \\
\hline Serine & 69 & 31 \\
\hline Threonine & 66 & 34 \\
\hline Tyrosine & 78 & 22 \\
\hline Tryptophen & 82 & 18 \\
\hline Valine & 43 & 56 \\
\hline
\end{tabular}

Enzyme activity has been measured by means of formation of aminoacyl-tRNA. The total number of units (specific activity $\times \mathrm{mg}$ of protein) of the distinct enzymes in supernatant $X$ and in the $\mathrm{X}$-fraction has been equalized to $100 \%$. Italics refer to amino acids with deviating behaviour.

TABLIE 2

Relative distribution of aminoacyl-tRNA synthetases during purification

\begin{tabular}{llllll}
\hline \multicolumn{1}{c}{ Purification step } & \multicolumn{7}{c}{ Tle } & Leu & $\begin{array}{c}\text { Amino acid } \\
\text { Met }\end{array}$ & Glu & Lys \\
\hline Post-microsomal cell sap & $1(1)$ & $2.0(1)$ & $0.8(1)$ & $0.3(1)$ & $0.4(1)$ \\
Crude X-fraction & $1(3.3)$ & $2.0(3.3)$ & $1.0(4-0)$ & $0.4(5.6)$ & $0.5(4.5)$ \\
Sephadex G200 & $1(35)$ & $1.9(34)$ & $1.2(49)$ & $0.3(32)$ & $0.8(72)$ \\
DEAE-Sephadex A50 & $1(53)$ & $2.1(56)$ & $1.2(76)$ & $0.3(59)$ & $0.6(80)$ \\
Hydroxyapatite & $1(135)$ & $1.7(115)$ & $0.9(146)$ & $0.3(132)$ & $0.5(168)$ \\
Isofoousing & $1 \dagger(-)$ & $1+(-)$ & $0.3 \dagger(-)$ & $0.3 \dagger(-)$ & $1.4 \dagger(-)$ \\
& & & & & \\
\hline
\end{tabular}

Enzyme activity was measured by ATP-pyrophosphate exchange and has been equalized to 1 for isoleucyl-tRNA synthetase in all purification steps. A purification factor expressed in relative units/mg of protein is given in parentheses.

$\dagger$ After isolelectric focueing the protein content was too low to allow protein determination. 

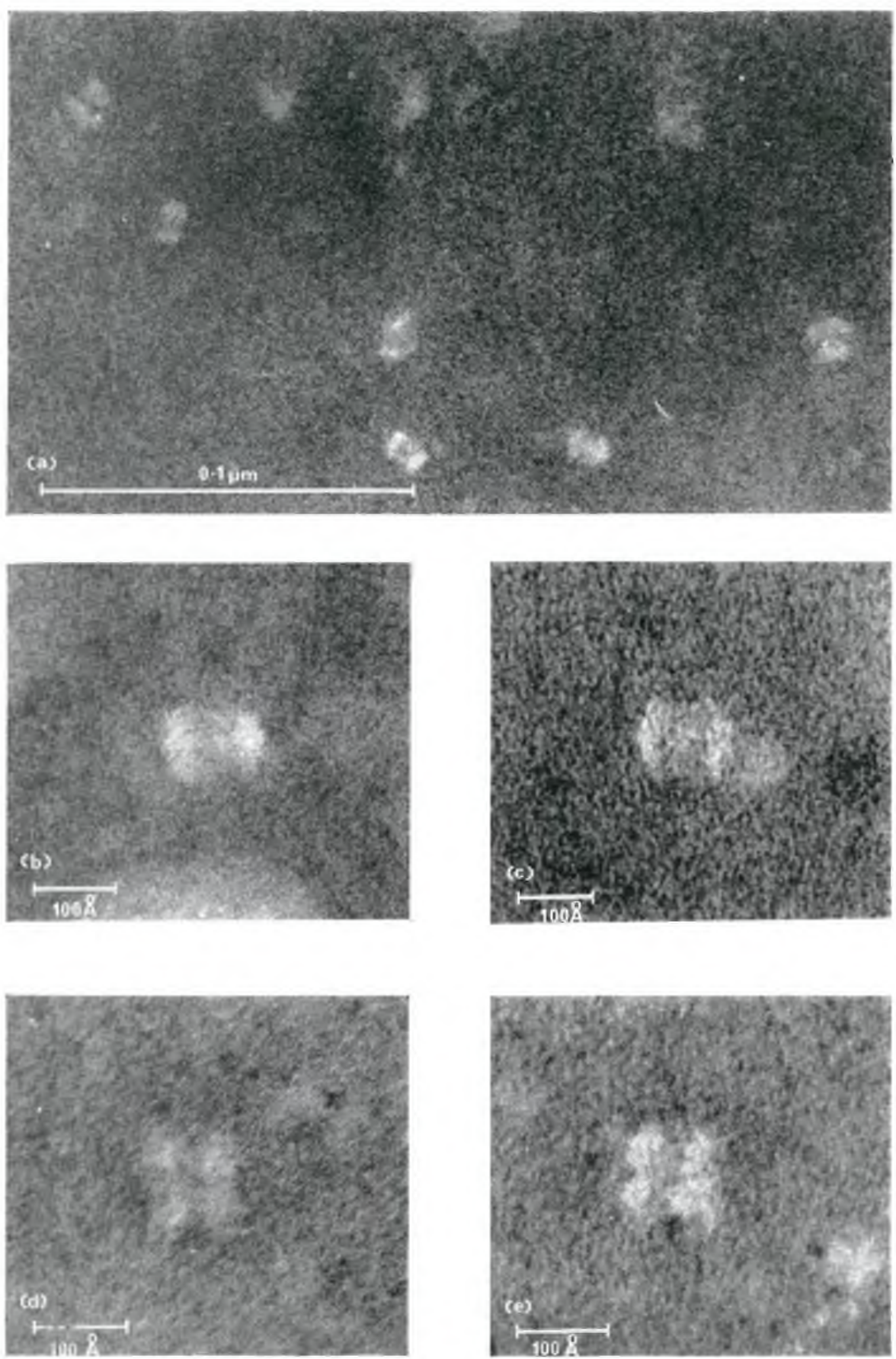

Plate I. Electron micrographs of the synthetase-containing fractions. The active fraction obtained after gel filtration on Sephadex G200 and chromatography on DEAE-Sephadex A50 is shown in (a), (b) and (c). Negative staining was with potassium tungstic acid, pH 6.8 . The active fraction after purification as in (a), followed by chromatography on hydroxyapatite and centrifugation in an isokinetic sucrose gradient, is visualized in (d) and (e). Negative staining was performed with uranyl formate, $\mathrm{pH} 7 \cdot 0$. 
TABLE 3

Distribution of glutaminyl-, isoleucyl-, leucyl-, lysyl-and methionyl-tRNA synthetase after isoelectric focusing

\begin{tabular}{lccc}
\hline \multicolumn{1}{c}{ Substrate } & $\begin{array}{c}\mathrm{p} I \text { 5.7 } \\
(\%)\end{array}$ & $\begin{array}{c}\mathrm{p} I \text { 6-1 } \\
(\%)\end{array}$ & $\begin{array}{c}\mathrm{p} I \text { 6.5 } \\
(\%)\end{array}$ \\
\hline & & & \\
Glutamine & 62 & 15 & 23 \\
Isoleucine & 55 & 20 & 25 \\
Leucine & 44 & 28 & 28 \\
Lysine & 90 & - & 10 \\
Methionine & 44 & 28 & 28 \\
\hline
\end{tabular}

The values are expreseed as percentage of total activity, which was measured both by aminoacid dependent ATP-pyrophosphate oxchange and formation of aminoacyl-tRNA.

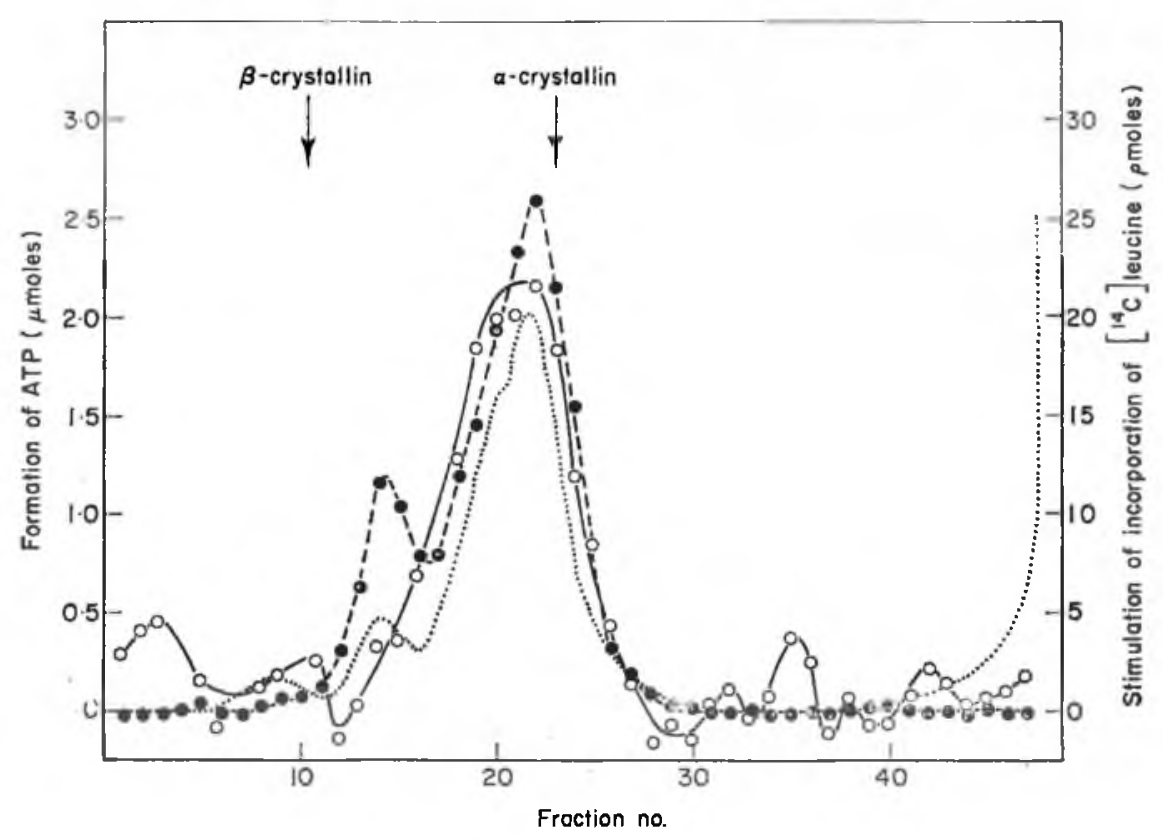

Fra. 1. Sedimentation profile of the purified X-fraction in an isokinetio sucrose gradient. Sucrose concentration at the top of the gradient was $15 \%(\mathrm{w} / \mathrm{v})$. Centrifugation was for $16 \mathrm{hr}$ in the SB283 rotor of the I.E.C. ultracentrifuge at $40,000 \mathrm{rev} . / \mathrm{min}$ and at $2^{\circ} \mathrm{C}$.

The X-fraction was purified by gel filtration on Sephadex G200 and ohromatography on DEAESephadex A50 and hydroxyapatite. Glutaminyl-, isoleuoyl-, leucyl-, lysyl- and methionyl-tRNA synthetase behaved identically in these purification steps. The curve represents the sum of the activities of these five enzymes, measured by amino-aoid dependent ATP-pyrophosphate exohange. Capacity to stimulate incorporation of $\left[{ }^{14} \mathrm{C}\right]$ leucine (indicated as protein synthesis) was assayed in the presenoe of polyribosomes and saturating amounts of the supernatant of the X-fraction.

The arrows indicate the position of $\alpha$ - and $\beta$-orystallin, which were centrifuged simultaneously in an identical gradient.

$-\mathrm{O}-\mathrm{O}-\mathrm{-}$, synthetase activity; $-\mathrm{O}-\mathrm{O}-$, protein synthesia; $. . . . \cdots \cdots, A_{284}$. 
bovine $\alpha$-crystallin with a sedimentation coefficient of $19.8 \mathrm{~s}$ and bovine $\beta$-crystallin $(7.9 \mathrm{~s})$ as markers, and assuming a particle density of 1.3 , a sedimentation coefficient of 18.2 $\mathrm{s}$ was derived for the major peak of activities of the five synthetases, and a value of $12.5 \mathrm{~s}$ for the minor peak, which contained only isoleucyl- and leucyl-tRNA synthetase activity (Fig. 1). The value of $18 \mathrm{~s}$ is considerably higher than can be expected from the data obtained for highly purified synthetases of Escherichia coli, yeast, bovine pancreas or rat liver, which range from 5 to $8 \mathrm{~s}$.

Bandyopadhyay \& Deutscher (1971) stressed that the complex of synthetases is not an artifact generated after rupture of the liver cells. Our electron microscopic observations support this view. Negatively-stained preparations of the purified $X$ fraction containing the five synthetases showed well-defined particles. The enzyme preparations obtained after gel filtration on Sephadex G200, followed by chromatography on DEAE-Sephadex A50, contained particles with a dumb-bell-like feature (Plate $I(a)$, (b) and (c)). This structure of the particles resembles those described by Shelton, Kuff, Maxwell \& Harrington (1970) which were, however, ascribed to transferase I activity. When the X-fraction was further purified by chromatography on hydroxyapatite and subsequently centrifuged in a sucrose gradient, the particles seemed to be converted to tetramers resulting from the aggregation of globularshaped subunits (Plate I (d) and (e)). These observations provide a more direct proof of an organized structure of aminoacyl-tRNA synthetases from rat liver.

A detailed account of all experimental procedures will be given elsewhere (Vennegoor \& Bloemendal, 1972).

Department of Biochemistry

University of Nijmegen, Nijmegen

Claudia J. G. M. Vennegoor

The Netherlands

A. L. H. StoLS

H. BLOFMENDAL

Received 17 September 1971, and in revised form 23 December, 1971.

\section{REFERENCES}

Bandyopadhyay, A. K. \& Deutscher, M. P. (1971). J. Mol. Biol. 60, 113.

Hoagland, M. B. \& Askonas, B. (1963). Proc. Nat. Acad. Sci., Wash. 49, 130.

Mizrahi, I. J. (1965). Biochim. biophys. Acta, 108, 419.

Noll, H. (1969). In Techniques in Protein Biosynthesis, ed. by P. N. Campbell \& J. R. Sargent, p. 101. London: Academic Press.

Parthier, B. \& Hultin, T. (1967). Biochim. biophys. Acta, 149, 562.

Shelton, E., Kuff, E. L., Maxwell, E. S. \& Harrington, J. T. (1970). J. Cell Biol. 45, 1.

Vennegoor, C. \& Bloemendal, H. (1970). Europ. J. Biochem. 15, 161.

Vennegoor, C. \& Bloemendal, H. (1972). Europ. J. Biochem. In the press. 
